\title{
Character Education Praxis in Namaku Teweraut by Ani Sekarningsih
}

\author{
$1^{\text {st }}$ Tobias Nggaruaka \\ Indonesian Language and Literature \\ Education Department, Faculty of \\ Teacher Training and Education \\ Universitas Musamus \\ Merauke, Indonesia \\ tobias.nggaruaka@gmail.com
}

\author{
$2^{\text {nd }}$ Ermelinda Agnes Gunu Pure \\ Primary School Teacher Education \\ Department, Faculty of Teacher Training \\ and Education \\ Universitas Musamus \\ Merauke, Indonesia \\ gunu@unmus.ac.id
}

\begin{abstract}
Literature is a reflective media for every person/reader. In literature, literature text contains life values which teach teachers to understand every sign or symbol used by the reader in sentences/dialogues in a literature text. By understanding sign or symbol, everyone can understand the meaning or message of literature text. This writing finds or reveals the character values in Namaku Teweraut. In education, using literature is a concrete way to cultivate character values in students. Habituation is inseparable from the moral responsibility of an educator who continuously educates the younger generation who has moral and dignity. The research focus was: (1) discipline character value, (2) leadership character value, (3) responsible character value, (4) social-cultural character value, and (5) hardworking character value. The five character values are concrete forms of character education praxis for students as the future generation who must be taught professionally. The characters could be taught through Namaku Teweraut is classroom teaching. The values in Namaku Teweraut could develop habits.
\end{abstract}

\section{Keywords-novel, character education, praxis}

\section{INTRODUCTION}

Literature as a semiotic wholeness can be viewed as a sign. Literature in writing has spatial property. The time and space dimensions in a fictional story (novel) contain signs which imply semiotic meaning [1].Message in a literature is related with the literature work itself. The meanings of literature are metaphorical, figures of speech, subjective, and special. To interpret a literature, reader should make sure that a fact is the evidence referred to by the author. Therefore, literature can show "evidence" to demand its readers to creatively interpret it. In analyzing a literature, reader should have creative principle. Creativity will enable reader to interpret meaning or message in it. Message in literature is usually not explicitly stated by author, but implied. To find implied message, a study is required [1]. Meanwhile, Maurice [2] considers literature as the special right of ownership of the middle class and the expression of the values. Freman [2] states that literature. They are all important, but we can study taste and sympathy.
The statements above show that literature can contribute to social life and even academic life (school). Literature contains life values, e.g. social-cultural, politic, and economy. They are all implied in literature. Using literature in school has positive impacts on students. There are many efforts to interpret sign or symbol to understand literature. Using many ways, readers will be able to understand the meaning or message implied in literature. Education is an agent that creates intelligent children with character. Education doesn't only create smart learner, but also should cultivate character values to prepare them for life. Young generation who has intelligence and character is the main goal of education. Many problems in the country today are worrying, so education is given to change the existing education paradigm. Character education praxis in education can give significant contribution to cultivating character values in students. Character education praxis is a breakthrough which is expected to create strong personality in students by developing their potentials, so with character education praxis life values can be cultivated in their lives. Regarding character education praxis, Bohlin, 1999 [3] argues that character education praxis is developing mind, health and action habits which enable individual to develop, i.e. using time, talent and energy well to achieve the best for themselves. The habituation process is performed in learning, particularly through fiction (novel), so finding character with good personality has good impacts on children and they can follow the attitudes of the character as a reflective action.

In Namaku Teweraut by Ani Sekarningsih, there are life values as parts of character which can be implemented in education at high school level (SMA/SMK) with application of character values in learning. This study was expected to have positive impact on the development of students. Implementation of character values, especially in the lives of the characters emphasized by author, is a reflective attitude of reader. By reading a literature (fiction) everyone is required to seriously interpret the life values implicit in it. Namaku Teweraut by Ani Sekarningsih describes the life of Asmat community (Papua) in social-cultural context with aspects of community order which upholds high levels of social life, hard work, mutual help, value of struggle, sociocultural, and 
religiosity. To get character values in the novel, analysis was performed using descriptive qualitative approach.

Character education praxis gives sufficient space oriented to character values to create moral and dignified younger generation. Character education believes in absolute moral, i.e. absulute moral should be taught to the younger generation so that they can distinguish good from bad. A literature contains signs, symbols, and moral, social and cultural values which are directly and indirectly contained in it. Literature isn't just symbol. Literature also contains visual and audio illusions which aren't bound to language convention. Therefore, the analysis of Namaku Teweraut by Ani Sekarningsih to understand character values focused on: (1) finding discipline character value, (2) leadership character value, (3) responsible character value, (4) social-cultural character value, and (5) hard-working character value.

\section{RESEARCH METHOD}

\section{A. The Method}

The method was qualitative research with descriptive research type because it prioritizes meaning, reasoning or definition of a situation or symptom in certain context. The approach was used by considering steps to review the meaning of literature based on reality, thus contributing to the lives of students. The interpretation of a literature was performed to understand the existing social values which were oriented to character education.

\section{B. Analysis Data}

The data was descriptive qualitative, requiring analysis to find meaning or social values in Namaku Teweraut by Ani Sekarningsih. According to Nawawi [4], description method means a problem-solving procedure by describing or illustrating problem the condition of research subject or object (person, institution, community, etc.) at the moment based on apparent facts or as is. Meanwhile, according to Siswantoro [4], a literature researcher must reveal apparent or observable facts by giving descriptions. Fact or data is a source of information which becomes basis of analysis. It means analysis was performed by presenting description as is, without intervention by the researchers. Interpretation is deciphering meaning in literature text (Namaku Teweraut) performed by the researchers, because the meaning of a literature isn't explicitly stated but implied by author in the literature.

\section{Data Analysis Techniques}

Qualitative method is a research procedure which produces descriptive data in the form of words, whether written or verbal from an interaction, as in data in Namaku Teweraut by Ani Sekarningsih. The data was obtained using documentation study or literature study on parts of the literature specifically. The data analysis technique was understanding the narrative text of Namaku Teweraut which could be used for social valueoriented character education praxis with literature sociological approach. The data was analyzed by (1) reading the entire narrative text of Namaku teweraut by Ani Sekarningsih, (2) making code in narrative text related with research focus, (3) classifying data based on study focus, (4) interpreting character values, (5) analyzing data or narrative text which had been sorted to get social values oriented to character education, (6) sorting data by character value which because study focus.

\section{RESULT AND DISCUSSION}

\section{A. Concept of Character Education Value}

Character education isn't just a learning material, but is more focused on learning process built in learning process which develops habituation and formation of students' character. Character education is education on noble character. Character education also isn't just moral and value lesson, but also continuously habituate [5]. Meanwhile, [6] states that the term character is used specifically in education starting from the $18^{\text {th }}$ century. The terminology of character refers to idealistic spiritual approach in education which is known as normative education theory. In regular and planned education process, character education is also strongly determined by the living environment of student, not only school but also student's home. Environment in education as stated by Nana Syaodih [7] consists of physical, social, intellectual and moral environments. Therefore, in learning at school, all aspects can determine the character of student based on their environment. Education is given through guidance, teaching, and training. Those activities are the main forms of character education. Character education refers to development of intellectual and moral abilities of student, so that the student has intellectual ability and morality. That's the purpose of education as stated in the educational philosophy base, but sometimes the application s inconsistent with the set purpose and expectation. According to Samani and Hariyato [8], character is defined as unique ways to think and act to live and work together in family, school community, nation and state. According to Miftah [9], character education is education which is oriented toward ability to problem solve, speak effectively, be brave in taking risk, have integrity, be honest, be trustworthy, be reliable, be tolerant, have noble character and be responsible. Character education is formed based on conducive environment. Environment greatly affects student's character development. If a student is born and raised in a conducive environment, they will have certain abilities which lead to character building. Conversely, environment which isn't conducive greatly affects student's behavior which leads them to "negative" things. Character building lasts a lifetime. Character will grow into people with character if they grow in environment with character.

In character building, there are three integrated matters. First, children understand good and bad, understand what action to take, is able to prioritize good things. Second love of virtue and hate of bad deeds, third children perform goodness, love others, love God and the universe [9]. Mashuri [3] states that character education is conscious decision of educator or school in planned way to create learning environment or culture which enables student to get valuable and useful experience to optimally develop their potentials, i.e. spiritual, personality, intellectual and skill potentials. 


\section{B. Concept of Discipline as Character Value in Namaku Teweraut}

Discipline can be interpreted as action which shows order, manners, compliance, and attention to rules as obligation in social life. In Namaku Teweraut by Ani Sekarningsih, value of discipline is implied in the narrative text dialogues. Series of dialogues show value of discipline implied in the narrative of Namaku Teweraut. The value of discipline in Namaku Teweraut by Ani Sekarningsih is found in:

Before I know it, I have worked for Mr. Mangunsong and Mister Hoover from Texas for four months. We live in a basecamp, a little remote from villages, which is a complex of "L" shaped board houses.

My morning task before they go to the oil drilling location is serving coffee with boiled taro. Sometimes, I serve chicken or curry flavored instant noodles to my employers. Afterward, I clean their sleeping cottages, sweep the porch, then wash the dishes and their t-shirts in the river."

Before I know it, my pregnancy enters its sixth month. There are movements which tickle the skin of my stomach, stunning me with the life inside". [10]

The quote shows that a character called Teweraut is a persistent and brave woman who works hard to provide for her family. Although her physical condition doesn't allow her to work hard, she wants to provide the family around her. Teweraut is a young village girl married to Akapits, who leaves her for a few months to look for work in Merauke Regency as a laborer in Merauke port. Teweraut, who is pregnant with her first child, must work hard to provide for herself and her family. She tirelessly works for employers with different cultures. For money, she works for Mister Hoover from Texas. Her job is exhausting, but she must do it. The girl's (Teweraut) attitude shows discipline and perseverance in performing duties and responsibilities as a housekeeper, despite her mental burdens.

\section{Concept of Leadership as a Form of Character Education Praxis in Namaku Teweraut}

The attitude of characters in Namaku Teweraut should be followed as lessons oriented to character values. Narrative text shows leadership, so students can understand that being a person who can lead class discussion, prayer, etc. requires long learning process. To be a leader, there should be guidance from teacher in character building, so that learning process which is continually designed has positive impact on children. A quote in Namaku Teweraut says:

nDiwiku is a respected man: famous for being a former warlord in his time. He is also a clan leader who also manages and holds every ritualistic ceremony, as well as traditional law and government, so he still receives the position as a traditional advisor in traditional house.[10]

The attitude of nDiwi (meaning Mister) shows that he's a warlord or a respected man in the community. Ndiwi isn't only a warlord but also an advisor in the community and has control function in social life. He sometimes decides on duties or policies. Responsibility is a form of devotion everyone must do.

\section{Value of Responsibility as a Form of Character Education Praxis in Namaku Teweraut}

The value of responsibility is interpreted as one's attitude and behavior in performing duty and responsibility to oneself, environment (social and cultural) and state, as well as religious obligations. The value of responsibility in the narrative text of Namaku Teweraut by Ani Sekarningsih is:

My morning task before they go to the oil drilling location is serving coffee with boiled taro. Sometimes, I serve chicken or curry flavored instant noodles to my employers. Afterward, I clean their sleeping cottages, sweep the porch, then wash the dishes and their t-shirts in the river."[10]

I'm also busy weaving ese or noken, and tapin. Endew prepares my new Awer, as well as new an I arranged using many tisen, ndrek, and cassowary feathers. [10]

The quote above shows that Teweraut's attitudes are forms of her responsibilities as a girl and Akapits' wife. Every task requires patience and sincerity as forms of responsibility. Teweraut does every task sincerely, despite her physical and psychological burdens. Teweraut's attitudes can be lessons for children to show them that everyone must struggle to get what they want.

\section{E. Social Cultural Moral Value as a Form of Character Education Praxis in Namaku Teweraut}

Social moral value is moral value related with direct and indirect relation among humans, for example in institution (family, community, and state) and responsibility to the life environment. Social moral value is value from norms in effect in the society. In the social life of Asmat tribe (Papua) has social values in their community life, e.g. mutual help, living side by side, and a number of social cultural values, as the community's identity. It's evident in how they build house together, own gatherer equipment and carving tools, method of doing certain tasks. The aspects of social value have unique meanings. The social moral value in Namaku Teweraut by Ani Sekarningsih is:

I live in a simple house which isn't as big as traditional house. It only has three door-less entries. Above every entrance, there are repelling charms. They consist of some types of eaves and roots magicked by with doctors. The number of entrances show that there are three people living in the house. Most houses are built using quite similar materials used by traditional house, jew traditional house has no partition to separate activities and usage of every room which cultivates separation of people, unlike what I usually see in the houses of newcomers in the sub-district. To replace partition, fire furnace plays an important role to determine the position of family member. My mother's 
furnace is right in the center of the room as she is the first wife. [10]

At the peak of the ceremony, a para-para made of dolken branches is prepared in front of jew's yard. mBis is carried out of the jew followed by mourning laments. When the crying stops, it's replaced by the pounding of tifa, and people all over the village dance. [10]

The quote above shows a social cultural phenomenon of Asmat people which reflects social attitude in their community and cultural lives. It's a call to live in an indiscriminating social life. Social value and call to live socially in simplicity should be cultivated in student's life as important lessons. Community life in simplicity is described in the quote above, showing that Asmat people have tradition and social values in their community life which can be learnt as character education praxis for the development of generation with character. Many social life problems which become social phenomenon should encourage people to change the educational paradigm which contributes to the development of smart, skillful, and dignified generation of the nation. The value of togetherness in community life is very dominant.

\section{F. Value of Hard Work as a Form of Character Education Praxis in Namaku Teweraut}

Value of hard work shows seriousness in performing duties, facing obstacles, and acting with responsibility. The value of hard work in Namaku Teweraut by Ani sekarningsih is:

Endew (Father) uses my presence to draw the passengers of Emperit (boat name) who disembarks or bring kiosk owners to shop on the boat or passengers heading toward the regency. It's not bad. We can ear three or five thousand rupiah to buy rice, instant noodles and a small can of sardines [10].

The attitudes of Endew (Father) and Teweraut are hardworking attitudes to fulfill their family's daily needs. Although irregular, they should be followed as they work hard to fulfill their family's needs. Although Teweraut is a woman, she helps her parents work to provide for her family.

\section{CONCLUSION}

Literature is a reflective media for every person/reader. In literature, there are life values which teach teachers to understand every sign or symbol. By understanding sign or symbol, everyone can understand the meaning or message of literature text. Using literature as a learning media can contribute meaningful lesson for the development of smart generation with character.
In Namaku Teweraut by Ani Sekarningsih, there are character values which should be applied in learning as habituation and cultivation of character values. The character values which became the study focus in Namaku Teweraut by Ani Sekarningsih were (1) discipline character value, (2) leadership character value, (3) responsible character value, (4) social cultural character value, and (5) hardworking character value. The five character values are concrete forms of character education praxis. Efforts should be made to give learning benefits for children to form their personalities. According to Miftah [9], character education is education which is oriented toward ability to problem solve, speak effectively, be brave in taking risk, have integrity, be honest, be trustworthy, be reliable, be tolerant, have noble character and be responsible. Character education is formed by conducive environment. Environment greatly affects student's character development. If a student is born and raised in a conducive environment, they will have certain abilities which lead to character building. Conversely, environment which isn't conducive greatly affects student's behavior which leads them to "negative" things. Character building lasts a lifetime. Character will grow into people with character if they grow in environment with character.

Literature is a very beneficial means of learning. It doesn't only provide entertainment for readers, but also cultivate life values, so literature in life is a reflective means for everyone. Namaku Teweraut is a novel which describes the life of Asmat people (Papua). The novel is written by Ani Sekarningsih based on the life of Asmat community (Papua) in Eastern Indonesia. The reality of life becomes political, cultural and economic lesson for everyone. The study is expected to benefit the readers.

\section{REFERENCE}

[1] P. Santosa, Ancangan Semiotika dan Pengkajian Susastra. Bandung: PT Angkasa, 2013.

[2] P. Barry, Pengantar Komprehensif Teori Sastra dan Budaya: Beginning Theory, 1st ed. Yogyakarta: Jalasutra, 2010.

[3] Mashuri, "Praksis Pendidikan Karakter Novel Negeri 5 Menara Karya Ahmad Fuadi," Pendidik. Hum., vol. 2, no. 1, pp. 11-21, 2014.

[4] Siswantoro, Metode Penelitian Sastra: Analisis Psikologi. Surakarta: Muhammadiyah University Press.

[5] Y. Abidin, Pembelajaran Bahasa Berbasis Pendidikan Karakter. Bandung: PT Refika Aditama, 2003.

[6] A. D. Koesoema, Pendidikan Karakter Strategi Mendidik Anak Di Zaman Global (Edisi Revisi), Ketiga. Jakarta: PT Gramedia Widiasarana Indonesia (Grasindo), 2015.

[7] N. S. Sukmadinata, Landasan Psikologi Proses Pendidikan, 6th ed. Bandung: Rosda, 2011.

[8] M. Samani and Hariyanto, Konsep dan Model Pendidikan Karakter, 1st ed. Bandung: Rosda, 2011.

[9] M. Zainul, Implementasi pendidikan karakter melalui bimbingan \& konseling, 1st ed. Surabaya: Gena Pratama, 2011.

[10] A. Sekarningsih, Novel Namaku Teweraut, 1st ed. Jakarta: Yayasan Obor Indonesia, 2000. 